\title{
Application of Antimicrobial Microcapsules on Agrotextiles
}

\author{
Marcela Ferrándiz ${ }^{1}$, Lucia Capablanca1, David García², Ma Ángeles Bonet ${ }^{3}$ \\ ${ }^{1}$ Instituto Tecnológico Aitex, Alcoy, Spain \\ ${ }^{2}$ Instituto de Tecnología de Materiales (ITM), Departamento de Ingeniería Mecánica y de Materiales, \\ Universitat Politècnica de València, Alcoy, Spain \\ ${ }^{3}$ Departamento de Ingeniería Textil y Papelera, Universitat Politècnica de València, Alcoy, Spain \\ Email: mferrandiz@aitex.es
}

How to cite this paper: Ferrándiz, M., Capablanca, L., García, D. and Bonet, M.Á. (2017) Application of Antimicrobial Microcapsules on Agrotextiles. Journal of Agricultural Chemistry and Environment, 6, 62-82.

https://doi.org/10.4236/jacen.2017.61004

Received: November 28, 2016

Accepted: January 21, 2017

Published: January 24, 2017

Copyright $\odot 2017$ by authors and Scientific Research Publishing Inc. This work is licensed under the Creative Commons Attribution International License (CC BY 4.0).

http://creativecommons.org/licenses/by/4.0/

(c) (i) Open Access

\begin{abstract}
The aim of this work was to develop a functional biodegradable nonwoven with antimicrobial microcapsules maintaining the stability and biodegradability of the nonwoven for use in agriculture applications. The nonwoven was obtained using hemp fibers by Wetlaid technology. Microcapsules were prepared by co-extrusion/gelling method with alginate as shell and oregano oil as core material. The microcapsules were developed to protect and control release of oregano oil. Microcapsules were incorporated on the nonwoven by coating method using a natural polymer as a graft material. After incorporating microcapsules, the nonwoven was subjected to several tests in order to determinate the microcapsules fixation and their functionality. The nonwovens were characterized for their antimicrobial activity against different kinds of bacteria and fungi. Nonwoven loaded with microcapsules was found to show good antimicrobial activity in comparison with nonwoven that was not loaded with microcapsules.
\end{abstract}

\section{Keywords}

Microcapsules, Oregano Oil, Co-Extrusion and Gelling, Coating, Hemp Agrotextil and Antimicrobial Activity

\section{Introduction}

Agrotextiles are a kind of engineering textiles used in the agriculture, horticulture, gardening and construction. Depending on the final application, the composition, production method and properties change.

Erosion Control Blanket (ECB) is a kind of agrotextile. It is aimed at strengthening the soil. It is composed by a high percentage of biodegradable natural 
fibers. The vegetable waste pruning can be processed by Wetlaid technology to obtain nonwoven for different applications of ECB or composites [1].

The Wetlaid is a processing technique highly used in the paper and textile industry for nonwoven formation. In the case of nonwoven textiles, it is possible to obtain nonwoven structures based on different base components both raw and waste materials so that it is possible to mix a base natural fibre with a binding fibre to provide cohesion after a thermo-bonding process [2] [3] [4]. The Wetlaid process, which uses highly diluted fibre-water dispersions, is an eco-friendly process since, although it consumes high water amounts, all the water is recirculated as it only acts as the fibre carrier component so that, almost all water is recovered in the hydroformer station in which nonwoven formation occurs [5].

The nonwoven or ECB can have an increase in its functional properties for agriculture by microcapsules incorporation.

Microencapsulation is a technology that allows sensitive materials to be physically enveloped in a protective "wall material", in order to protect these ingredients or "core" materials, from adverse reactions, volatile loss, weathering, etc. The selection of wall material for each core material is important; i.e., carbohydrates such as maltodextrins [6] [7] [8] [9], starches [10] [11], Arabic gum [12] [13], alginate [14] [15], chitosan [16] [17], or mixtures thereof [18] [19] [20] [21], etc., have been all widely used as encapsulation agents.

Biopolymers, like alginate, are used as encapsulating materials in several applications, more commonly, in food and pharmaceutical applications. This polymer is not supposed to affect the encapsulated compound activity [22]; it shows high toughness and it has considerable effects on the mechanical stability of beads [23].

Many essential oils, such as garlic, oregano, cinnamon, thyme, basil, eucalyptus, rosemary, peppermint, etc., have been demonstrated to show antimicrobial activity [23]. Therefore, these natural products are an alternative to replace synthetic chemical pesticides [24].

The biological activity of these oils can be lost by volatilization of active components or their degradation by act of high temperatures, oxidation and UV light [25]. These disadvantages make the commercial application of these oils limited.

Microencapsulation, as one of the most efficient methods for the protection of essential oils, has to be employed for controlling the release of active ingredients and protecting them from the external environment.

Many researches are done on microencapsulation of essential oils using several methods including spray-drying, simple coacervation, complex coacervation, co-extrusion/gelling, supercritical fluid precipitation, etc. [23]. Co-extrusion/gelling is considered as one of the most common approaches of microencapsulation [26]. This process happens when a fluid flows in laminar state and breaks into droplets of a same size through an overlapped vibration. Then these drops transform into a gel in an ionic solution, resulting in the encapsulation of the active ingredient (Core) with a polymer (Shell) [27] [28]. 
There are several methods for applying microcapsules in agrotextiles, like padding, bath exhaustion, printing, coating, etc. In all of them, the microcapsule's shell is not usually an agent that can react with the fibers, so it is necessary to make them adhere to the fiber by means of a resin, otherwise they will be lost [29].

In the textile industry, the most common resins are: acrylics, polyurethanes, silicones, etc., all of them are synthetic, and for agriculture application are not suitable due to their low degradability. Biodegradable polymers, like chitosan, become an alternative to the use instead of chemicals [30].

Chitosan is a natural biopolymer that is derived from chitin by chemical, electrochemical or enzymatic methods [32]. It has unique properties that make it very interesting for medical, agricultural and food applications. It has high antimicrobial activity [31]; It is biocompatible [32]; nontoxic [33]; strengthens the plants [34] and; it has functional properties as a dietary supplement [35] among others.

Besides, chitosan has the ability to form hydrogels, dimensional polymeric networks with high water absorption capacity [27], which is very interesting from agricultural point of view.

In the last years, a growing interest on the use of biobased materials or materials from renewable resources has been detected. This interest has also arrived to technical sectors such as agriculture. Therefore, the use of natural and renewable materials for the control of erosion in the soil [36], the use of the molecules with biological activity to control the microorganisms [37] and the use of natural biopolymer to functionalized agricultural systems [38] [39] open a wide range of possibilities from the point of view of sustainable agriculture.

The aim of the present study is to develop a functional and biodegradable ECB for agriculture applications. For that, the first task is the revalorization of hemp wastes in textile nonwoven industry using the wetlaid technology to obtain an ECB. To provide high cohesion on nonwovens, different binder fibers have been used: Lyocellfibre and PLA fiber.

The second task is the microencapsulation oregano essential oil by co-extrusion/gelling method using alginate as shell material. The main chemical thermal and functional properties are determined by standardized test.

The third task is the functionalization of hemp nonwoven with the microcapsules application on its surface. To provide high durability the microcapsules on the nonwoven a biopolymer have been used. The main properties such as air permeability, antimicrobial are determined by standardized test.

\section{Materials and Methods}

\subsection{Materials}

\subsubsection{Materials for Microcapsules Formation}

A low viscosity alginic acid sodium salt from brown algae with $3 \%$ and $5 \%(\mathrm{p} / \mathrm{v})$ supplied by Sigma Aldrich (Spain) was used as shell material. 
The core material was an essential oil, oregano oil, supplied by Esencias Lozano (Spain).

Calcium chloride supplied by Sigma Aldrich (Spain) was used as cross-linking agent for microcapsules formation and it was prepared at $0.5 \mathrm{M}$.

In order to determinate the oil by spectrophotometry was used an oil soluble dye, Verde Cornasol C (Prochimac, Switzerland), this dye was mixed with oregano oil.

\subsubsection{Material for Hemp Nonwoven Development}

A hemp nonwoven was used as a substrate. This kind of nonwoven is used as agrotextil, specifically like Erosion Control Blanket. Prototypes used in the research were produced by Materials Research Group from Textile Technology Institute (AITEX, Spain).

Hemp agrotextil was obtained by wet-laid process with a $150 \mathrm{~g} / \mathrm{m}^{2}$; it was composed of $80 \%(\mathrm{w} / \mathrm{w}$ ) of hemp residue supplied by STW (Germany). As well as two other fibers biodegradable fibers those allow nonwoven to be consolidated: $10 \%(\mathrm{w} / \mathrm{w})$ of polylactic acid (PLA) supplied by Mini fibers (Germany) with $6.3 \mathrm{~mm}$ of length and $1.3 \mathrm{dpf}$ of thickness; and $10 \%(\mathrm{w} / \mathrm{w})$ lyocell supplied by STW (Germany) with $4.0 \mathrm{~mm}$ of length and 1.7 dtex of thickness.

\subsubsection{Materials for Nonwoven Functionalization}

A medium molecular weight chitosan supplied by Sigma Aldrich (Spain) was used to prepare a gel, which formed a three dimensional network that traps the microcapsules and fixed on the nonwoven.

Sodium tripolyphosphate (TTP) supplied by Sigma Aldrich was used as crosslinking material in order to form the polymer network on the textile substrate and stabilize the coating.

\subsection{Methods}

\subsubsection{Microencapsulation Process: Co-Extrusion/Gelling}

Microcapsules were obtained by BUCHI B-390 at room temperature. The internal nozzle diameter (core) was $0.2 \mathrm{~mm}$ and the external nozzle diameter (shell) was $0.4 \mathrm{~mm}$. Potential and frequency values were $250 \mathrm{~V}$ and $350 \mathrm{~Hz}$. Oil flow and alginate flow were controlled by injection pump $(900 \mathrm{~mL} / \mathrm{h}$ and $300 \mathrm{~mL} / \mathrm{h}$ respectively), this difference is due to the solution viscosity. These experimental parameters were optimized in a previous research [40] [41] (Table 1).

The optimal parameters were selected based on:

- the final bead size;

- final capsule size;

- the core size (amount of oil inside);

- stability of microcapsules;

- morphology of microcpasules.

So, microcapsules were filtered and washed for three times with distilled water in order to eliminate all the calcium chloride solution in the microcapsules wall

(Figure 1) [28]. 
Table 1. The parameters studied and optimal parameters.

\begin{tabular}{ccc}
\hline & Parameters studied & Optimal parameters \\
\hline Potential $(\mathrm{V})$ & $500,400,350,300$ and 250 & 250 \\
Frequency $(\mathrm{Hz})$ & 400,300 and 200 & 350 \\
Alginate flow $(\mathrm{mL} / \mathrm{h})$ & 900,800 and 700 & 900 \\
Oil Flow $(\mathrm{mL} / \mathrm{h})$ & 900,500 and 300 & 300 \\
Alginate $(\%)$ & $1,2,2.5,3,3.5$ and 4 & 3.5 \\
Calcium chloride $(\mathrm{M})$ & $0.1,0.25,0.5$ and 0.75 & 0.5
\end{tabular}

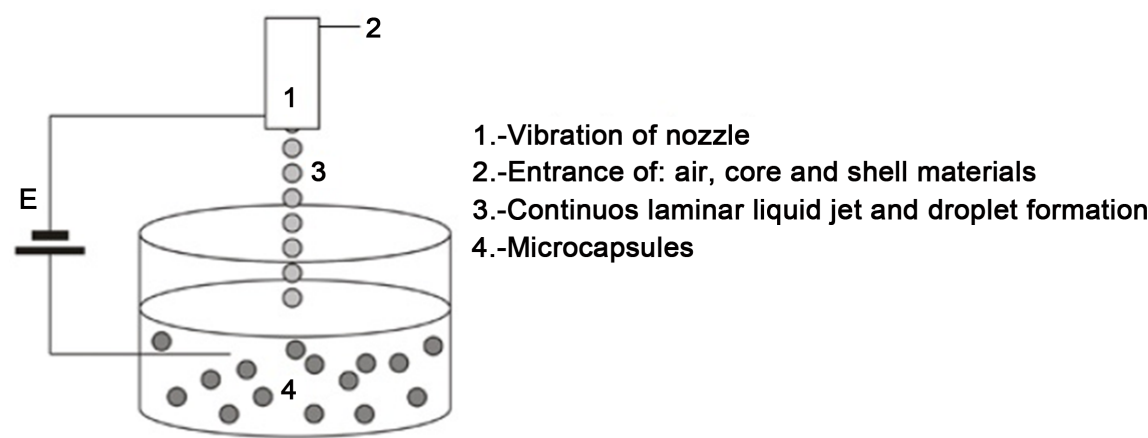

Figure 1. Microcapsules formation.

Next diagram shows the microcapsulesobtaining process:
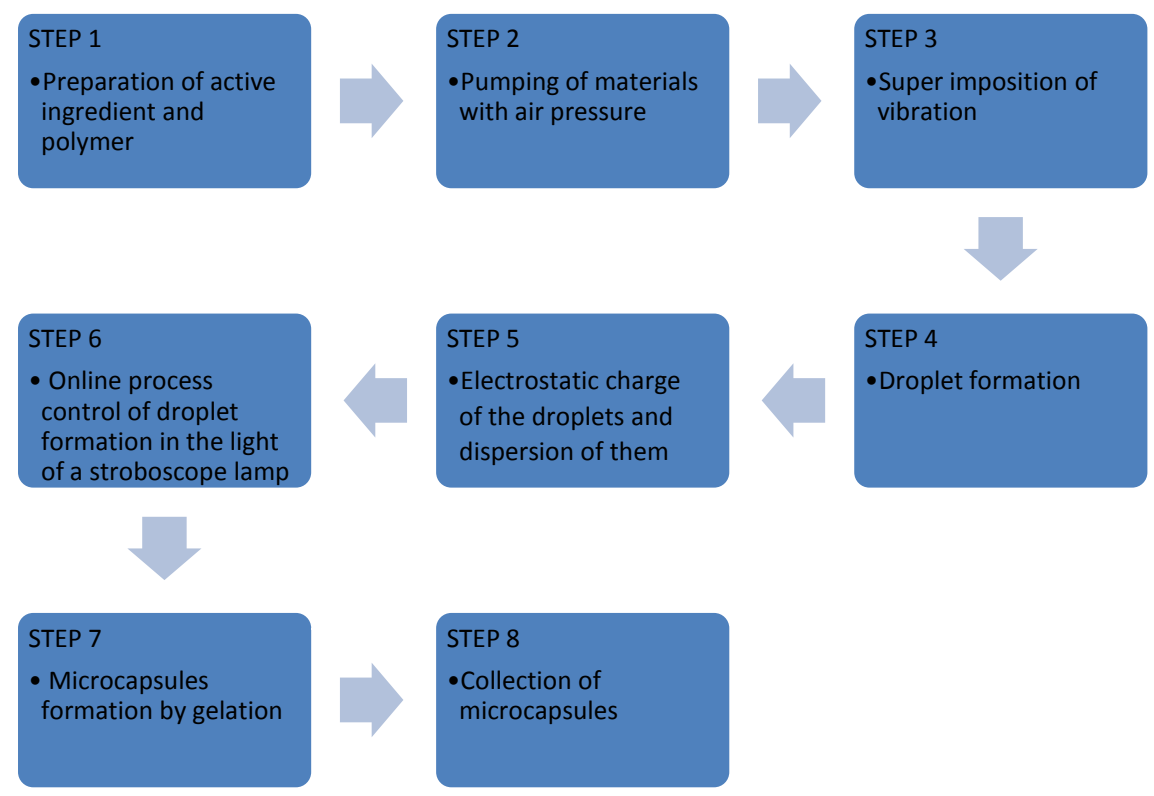

\subsubsection{Microcapsules Characterization \\ Morphology:}

Microcapsules morphology was studied in an optic microscope AM4115ZT Dino-Lite Edge (Dino-Lite Digital Microscope, Taiwan) with a Dino-Capture Software.

The experiments were done with dry and non-dry microcapsules. They were repeated four times to compare the results between different microcapsules. 


\section{Differential scanning calorimetry:}

Differential scanning calorimetry Mettler-Toledo 821 (Mettler-Toledo Inc., Switzerland) was used to determinate the glass transition temperatures ( $\mathrm{Tg}$ ) of the dried microcapsules. Approximately $10 \mathrm{mg}$ of sample (dry microcapsules) was prepared in aluminum pans in air atmosphere. The curves were obtained according to the following heating program from $0^{\circ} \mathrm{C}$ to $220^{\circ} \mathrm{C}$ at $5^{\circ} \mathrm{C} / \mathrm{min}$.

\section{Thermogravimetry:}

Thermogravimetry (TGA/SDTA 851, Mettler-Toledo Inc., Switzerland) was used to determine the stability of the microcapsules at high temperatures. Approximately $70 \mu \mathrm{L}$ of sample (dry microcapsules) was prepared in aluminum pans. The thermal program was located between $0^{\circ} \mathrm{C}$ and $220^{\circ} \mathrm{C}$ at $10^{\circ} \mathrm{C} / \mathrm{min}$ under nitrogen gas with a flow rate of $60 \mathrm{ml} \cdot \mathrm{min}^{-1}$.

Fourier-transform infrared spectroscopy (FTIR):

Samples were analysed in an Infrared spectra Varian FT-IR 670 with a 0.10 $\mathrm{cm}^{-1}$ resolution for each infrared spectrum. Spectra were collected in ATR mode.

\section{Determination of encapsulated oil:}

Control release was made with a spectrophotometric technic UV (Evolution 60S, Thermo Scientific, USA). It was necessary to use a dye (Verde Cornasol C) in this technique due to the fact that oregano oil is colorless.

First, was necessary to determinate de calibration curve at $647 \mathrm{~nm}$. For this four solutions were prepared by dilutions 1:2 to the first solution (oregano oil + $1 \%$ dye).

The experiments were made with $0.5 \mathrm{~g}$ of non-dry and dry microcapsules. They were repeated three times. To release the oil, it was put the same quantity of microcapsules and $5 \mathrm{ml}$ of ethanol, and then sonicated for 10 minutes. The room conditions were $25^{\circ} \mathrm{C}$ and $60 \%$ oh humidity.

The oil content was calculated by Lambert-beer method.

\section{Antimicrobial test:}

Oregano essential oil and the microcapsules were tested to determinate antifungal/antibacterial activity, based on Standard ASTM E 2149-13 where colony-forming unit (CFU or cfu) is a measure of viable bacterial or fungal cells. The contact time of the material with fungi was $24 \mathrm{~h}$ and the Culture medium used was Sabouraud Dextrosa Agar (Sharlab, Spain). The contact time of the material with bacteria was $24 \mathrm{~h}$ and the Culture medium used was plate Count Agar (Sharlab, Spain). The Incubation temperature was $35^{\circ} \mathrm{C} \pm 2^{\circ} \mathrm{C}$.

It is necessary to mention that before the test microcapsules were broken to allow release oil using a mortar.

\subsubsection{Obtaining Hemp Nonwoven}

In a first stage, hemp wastes, Lyocell and PLA fibers were weighed and immediately they were poured into a pulper with a maximum capacity of $35 \mathrm{~L}$. This pulper was supplied by PILL Nassvliestechnik (PILL Nassvliestechnik GmbH, Germany). The fibre concentration in the water dispersion was $10 \mathrm{~g} / \mathrm{L}$. To obtain optimum fibre separation, vigorous agitation at $2300 \mathrm{rpm}$ was maintained for 10 min. After this initial stage, the water dispersion is transferred to a larger polye- 
thylene tank in which, the fibre dispersion is diluted up to $1 \mathrm{~g} / \mathrm{L}$ with less aggressive agitation at $170 \mathrm{rpm}$ for a period of time of $15 \mathrm{~min}$. Then, once the fibers are appropriately dispersed in aqueous solution the water-fibre mixture is moved to the hydroformer station by using hydraulic pumps. The hydroformer station has been supplied by PILL NASSVLIESTECHNIK GmbH. The water-fibre dispersion is pumped to the hydroformer station, and the water-fibre dispersion is dropped onto the porous forming strip which acts as a filter media in which water is removed by vacuum and fibers are deposited.

Once the nonwoven is formed, additional thermo-bonding process must be carried out in order to melt PLA fibers to embed hemp wastes thus increasing nonwoven cohesion. A first drying stage was carried out initially in a drying oven SDT-600 by Tacome (Tacome S.A., Spain) at a fixed temperature of $195^{\circ} \mathrm{C}$ for $15 \mathrm{~min}$. After this stage, the dried nonwoven is subjected to a calendaring process in a CL-600 calendar supplied by Tacome (Tacome S.A., Ontinyent, Spain). The surface temperature of the roller was maintained to $200^{\circ} \mathrm{C}$ and the linear pressure over the nonwoven was fixed to $0.124 \mathrm{MPa}$.

\subsubsection{Microencapsules Application Process on Nonwoven}

Microcapsules were applied by coating using a chitosan gel. A scraper laboratory model CH-8156 supplied by Mathis (Zurich) with $3.5 \mathrm{~mm}$ of gauge was used in the process.

The gel was prepared with $4 \%(\mathrm{w} / \mathrm{w})$ medium molecular weight chitosan. Chitosan was dissolved with acetic acid (1\%v/v). Both products were supplied by Sigma Aldrich (Spain).

Oregano microcapsules concentration into gels was $30 \mathrm{~g} / \mathrm{l}$. This amount was optimized in previous researches, and if this concentration is increased the antimicrobial effect don't improve.

10mL Sodium tripolyphosphate (TTP) supplied by Sigma Aldrich (Spain) 1\% $(\mathrm{w} / \mathrm{v})$, was used as cross-linking material in order to form the polymer network on the textile substrate and stabilize the coating, it was applied by spraying.

After application, nonwovens were dried at room temperature $\left(20^{\circ} \mathrm{C} \pm 2^{\circ} \mathrm{C}\right)$.

\subsubsection{Functional Nonwoven Characterization}

\section{Morphology:}

Surface morphology was studied in an optic microscope AM4115ZT Dino-Lite Edge (Dino-Lite Digital Microscope, Taiwan) with a Dino-Capture Software.

\section{Determination of surface Mass:}

The standard UNE-EN 12.127:1998 was used in order to determine the mass per unit area. The Atmosphere for conditioning and testing: Temperature: (20 \pm $2)^{\circ} \mathrm{C}$; Relative humidity: $(65 \pm 4) \%$.

The test has been carried out an original nonwoven (untreated), nonwoven with chitosan gel and nonwoven with chitosan gel + microcapsules.

\section{Air permeability:}

Air permeability test is conducted using an Air Permeability Tester FX 3300 Textes Ag Zurich, Switerland (UNE-EN ISO 9237:1996) with $200 \mathrm{~Pa}$ of pressure. 
Atmosphere for conditioning and testing: Temperature: $(20 \pm 2)^{\circ} \mathrm{C}$; Relative humidity: $(65 \pm 4) \%$.

\section{Water column test:}

The test determined the resistance to water penetration of the nonwovens following the standard UNE EN 20811.

This International Standard describes a method under hydrostatic pressure test to determine nonwoven resistance to water penetration.

The test has been carried out on the original nonwoven, nonwoven with chitosan gel and nonwoven with chitosan gel + microcapsules in order to determine how the coating affects the water penetration.

Atmosphere for conditioning and testing: Temperature: $(20 \pm 2)^{\circ} \mathrm{C}$; Relative humidity: $(65 \pm 4) \%$.

\section{Nonwoven weatherability resistance:}

Nonwovens were exposed outdoor on a grave surface in contact with the land, during 35 days in Muro de Alcoy (Alicante, Spain), altitude (meters over the sea level) 413 and geographical position: $38^{\circ} 48^{\prime} 41.76^{\prime \prime} \mathrm{N}, 00^{\circ} 24^{\prime} 37.08^{\prime \prime} \mathrm{W}$.

Previously to conduct the test, all samples were weighed (SE 1501, VWR) because the aim was to determine the weight loss, because may be the chitosan is degradated.

Nonwoven surface was observed in an optic microscope AM4115ZT DinoLite Edge supplied by Dino-Lite Digital Microscope (Taiwan) with a DinoCapture Software. Also nonwovens were weighted in the laboratory in standard conditions in order to avoid differences due to the environmental parameters (temperature, moisture, UV radiation, etc.).

\section{Antimicrobial test:}

Hemp nonwovens, hemp nonwovens with chitosan gel and hemp nonwovens with chitosan and oregano microcapsules, were tested to determinate antimicrobial properties, the test is based on Standard ASTM E 2149-13, and in this test was determinated the colony-forming unit (cfu).

The contact time of the material (nonwovens) with fungi was $24 \mathrm{~h}$ and the culture medium used was SabouraudDextrosa Agar supplied by Sharlab (Spain). The Incubation temperature was $28^{\circ} \mathrm{C} \pm 2^{\circ} \mathrm{C}$.

\section{Results}

\subsection{Microcapsules}

\subsubsection{Morphology}

The results obtained when analysing the microcapsules show that non-dry ones were not completely spherical. The core material has a spherical shape and the oil is located inside the wall as it can be observed in Figure 2.

The results of the morphology study are shown in Table 2 . It can be observed that due to the core morphology, dry microcapsules presented more spherical shape than non-dry microcapsules. Non-dry microcapsules area was bigger than the one from the dry microcapsules. This is due to water loss in the drying process. 

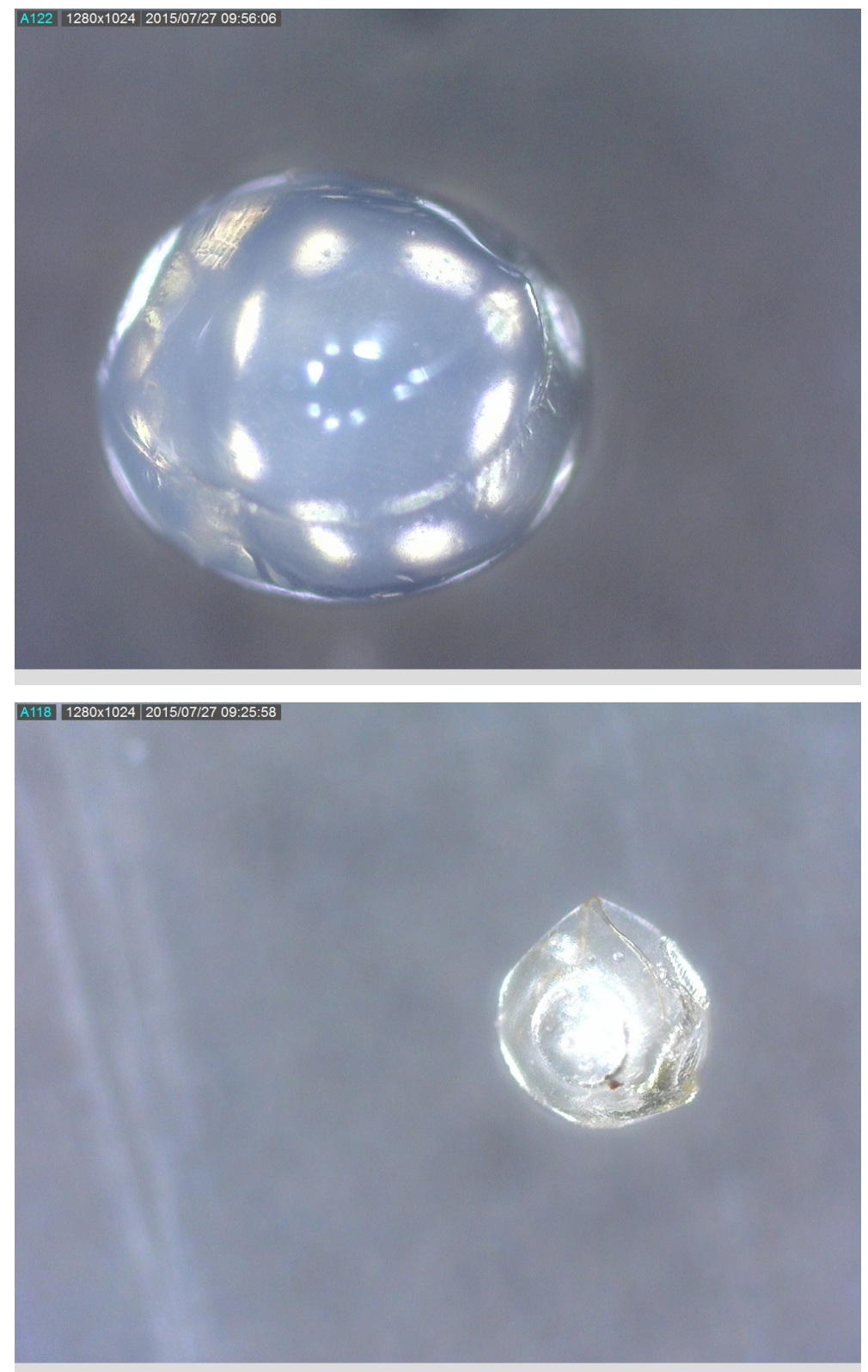

Figure 2. Upper: Non-dry microcapsule (163.2×); Down: Dry microcapsule (167.8×).

Table 2. Morphology values of non-dry and dry microcapsules.

\begin{tabular}{cccc}
\hline \multirow{2}{*}{ Microcapsules } & \multicolumn{3}{c}{ Morphology Parameters } \\
\cline { 2 - 4 } & Area $\left(\mathrm{mm}^{2}\right)$ & Diameter microcapsule $(\mathrm{mm})$ & Membrane Thick $(\mathrm{mm})$ \\
\hline Non-dry & 0.709 & 0.950 & 0.273 \\
Dry & 0.449 & 0.756 & - \\
\hline
\end{tabular}

Certain differences can be observed between size microcapsules obtained (Table 2) and the external nozzle diameter $(0.4 \mathrm{~mm})$. This is due to equipment parameters like vibration frequency, flow rate, electrode tension, separation distance of the nozzle to the bath, the effect of gravity, the surface tension of the inducing gelation solution, the gel time, alginate viscosity, etc., all of them have influence in the microcapsules sizes [42]. 
Differences in microcapsules size between non-dry and dry microcapsules is due to hydration of the alginate, alginate hydrogel has these properties [43].

For this kind of microcapsules it is difficult to calculate the size by any other method except the microscopy. In the past we tried with Coulter ${ }^{\oplus}$ Counter and we concluded that it is not a good way to determine the size of the alginate microcapsules due to the use of isotonic solution [27].

\subsubsection{Differential Scanning Calorimetry}

Thermal analysis has been studied in order to determine the microcapsules thermal characteristics and predict their thermal behaviour.

Figure 3 shows the DSC thermograms of the oregano, the polymer from the shell (alginate) and the micro-capsules containing oil and the shell respectively. In Figure 3 it can be observed an endothermic transition at $190^{\circ} \mathrm{C}$, and this temperature is attributed to the evaporation temperature of oregano oil. Microcapsules and the shell polymer have and endothermic transition at $80^{\circ} \mathrm{C}$ this temperature is attributed to the dehydration of the alginate. These temperatures demonstrate that drying temperature $\left(60^{\circ} \mathrm{C}\right)$ doesn't affect the microcapsules, therefore microcapsules can be dry after coating process to fix on the nonwoven.

\subsubsection{Termogravimetry}

Figure 4 shows the TGA thermograms of the oregano oil, the polymer (shell) and microcapsules. Oregano oil shows the evaporation temperature at $190^{\circ} \mathrm{C}$, and at $60^{\circ} \mathrm{C}$ starts evaporation. This results matches with DSC analysis. In figure 4 , it can be observed three curves corresponding to the oregano oil, alginate as polymer used as wall material and oregano microcapsules obtained by co-extrusion/gelling with alginate shell.

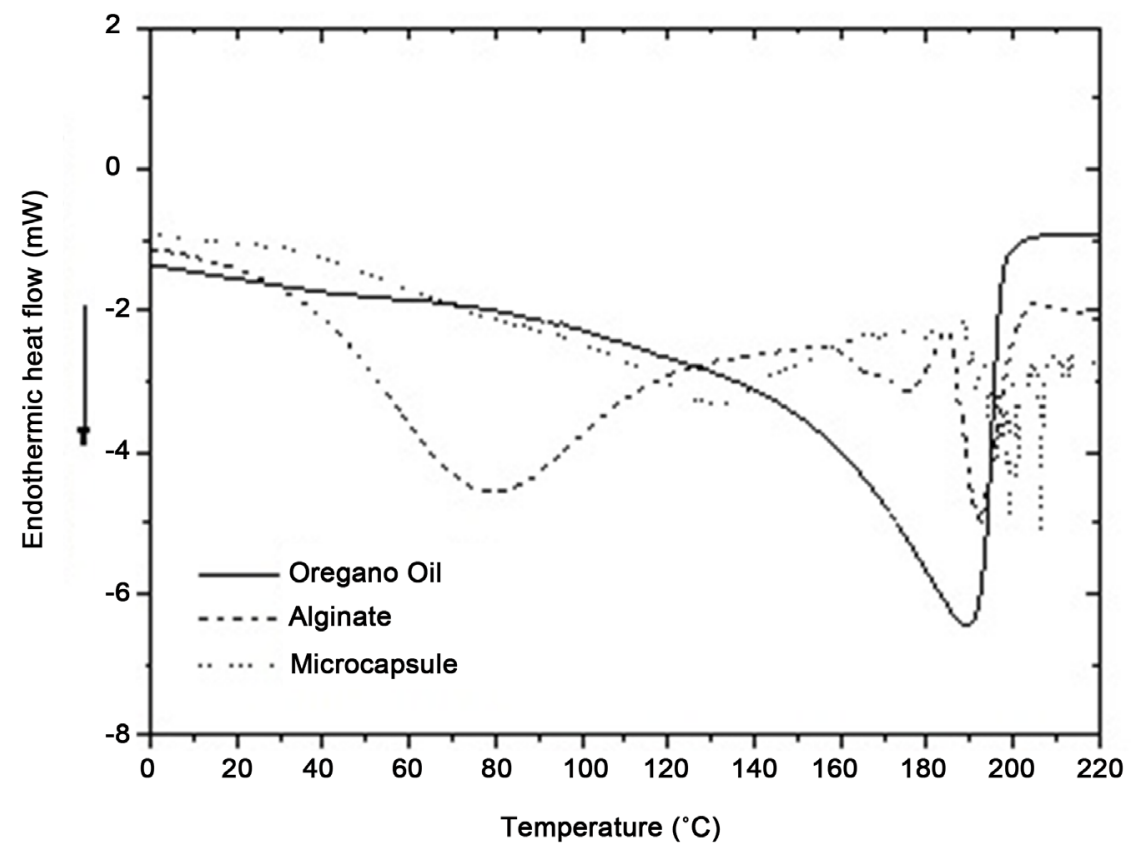

Figure 3. Differential scanning calorimetric diagram of oregano oil, wall material and microcapsules. 


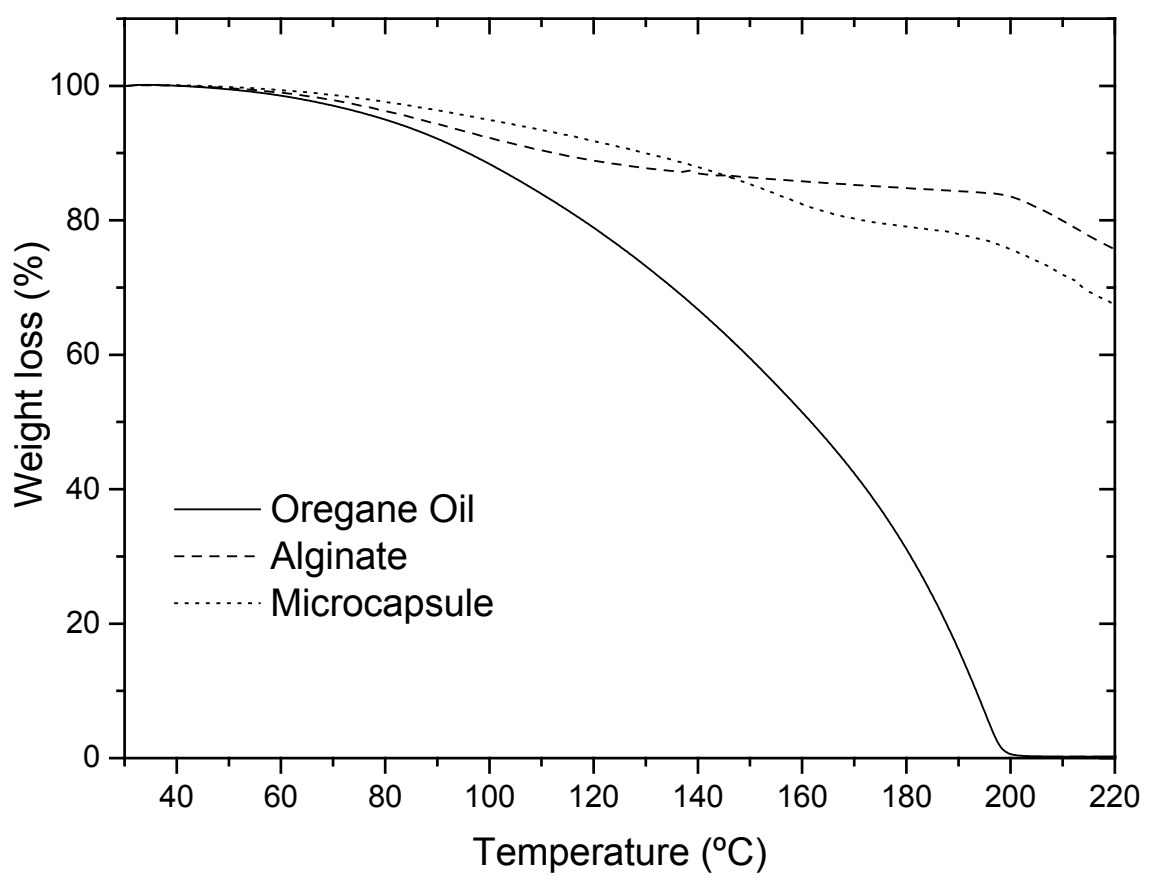

Figure 4. Three curves corresponding to the oregano oil, wall material and microcapsules.

The weight loss starts at $80^{\circ} \mathrm{C}$ in microcapsules due to the indoor humidity evaporation, because the outdoor humidity is removed in the drying process to turn them into powder form.

\subsubsection{Fourier-Transform Infrared Spectroscopy (FTIR)}

FTIR test was conducted in order to characterize the microcapsules. Figure 5 shows the spectra for three compounds, oregano oil, the alginate and the microcapsules.

When the study is centred in the region between $3800-2000 \mathrm{~cm}^{-1}$, two important zones can be observed. The first one is comprised between $3800-3100$ $\mathrm{cm}^{-1}$ and is attributed to O-H bonding, the second one is located around 3100 $2600 \mathrm{~cm}^{-1}$ and is assigned to $\mathrm{C}-\mathrm{H}$ stretching. All the samples show picks at both regions. Thus can be attributed to the oregano oil, which is composed in majority of carvacrol and thymol [41] [43] [44].

When the oil has been encapsulated, the picks moved towards a different wavenumber. The alginate shell shows a pick between $3.242 \mathrm{~cm}^{-1}$ due to the $\mathrm{O}-\mathrm{H}$ stretching, around $1.081-1.024 \mathrm{~cm}^{-1}$ is located a pick attributed to COC stretching [45] [46] [47].

Alginate is crosslinked with calcium chloride, therefore, it is possible to observe two bands displaced relative to sodium alginate:

-1.596 until $1606 \mathrm{~cm}^{-1}$ (carboxylate ion);

-3.242 until $3.337 \mathrm{~cm}^{-1}$ due to the sodium alginate interaction.

The FTIR spectrum confirms the existing core material and oregano oil inside the microcapsules. 


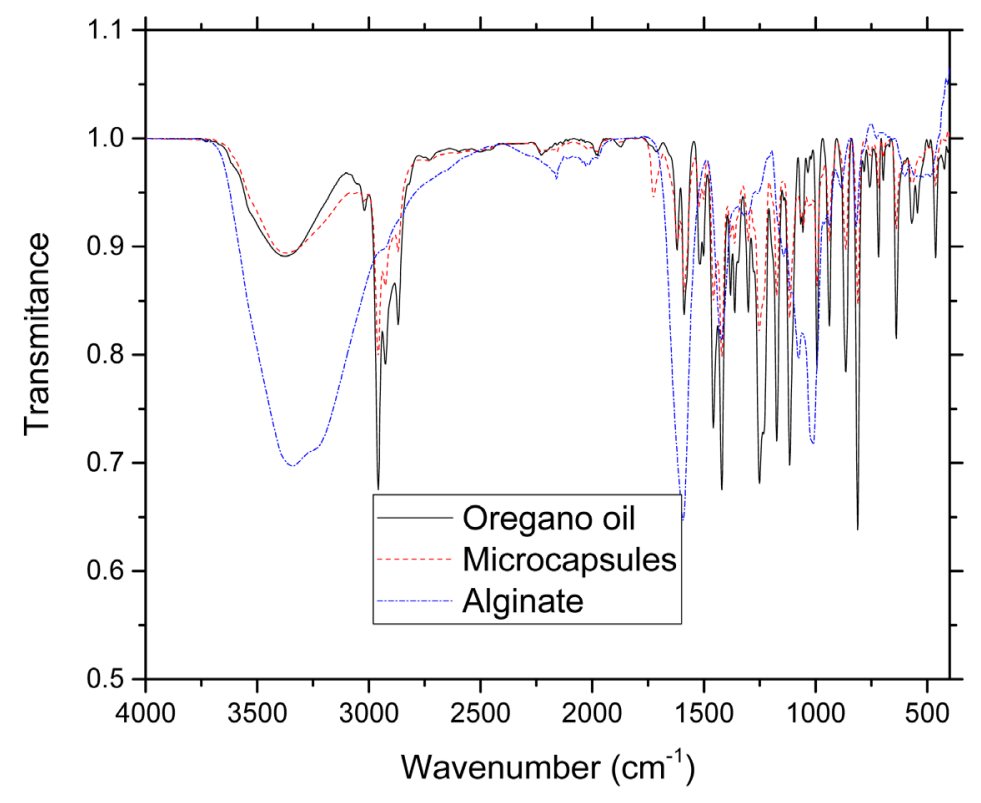

Figure 5. FTIR spectra from the oregano oil and microcapsules.

\subsubsection{Determination of Encapsulated 0il}

As a result of the control release the concentration of oil has been calculated with the Lambert-Beer law:

$$
A=\varepsilon * l * c
$$

where

$$
\begin{aligned}
& A=\text { Absorbance } \\
& \mathcal{E}=\text { Molar absorptivity; } \\
& I=\text { Path length in } \mathrm{cm} ; \\
& \mathcal{c}=\text { Molar Concentration. }
\end{aligned}
$$

Monitoring of control release has been realized during 120 hours, at this time all the oil has been delivered and the total concentrations are

Coreg oil $=9.120 \pm 0.001 \mu \mathrm{g} \cdot \mathrm{mL}^{-1}$ for non dry microcapsules

Coreg oil $=8.994 \pm 0.001 \mu \mathrm{g} \cdot \mathrm{mL}^{-1}$ for dry microcapsules

The results show that the difference values were non-significant.

\subsubsection{Antimicrobial Test}

Oregano essential oil and microcapsules were tested as an antimicrobial and antifungal. They presented an excellent reduction at the bacteria and fungi population. Results are showed in Table 3.

Oregano oil and microcapsules showed good antimicrobial activity [23] [24] [48], this result demonstrated that the oil has been successfully encapsulated because the control tested, alginate didn't show antimicrobial activity, the encapsulation methods didn't affect the antimicrobial activity of the oregano oil.

\subsection{Functional Nonwoven}

\subsubsection{Morphology}

Figure 6 shows the image of hemp nonwovens after coating and TTP application. 


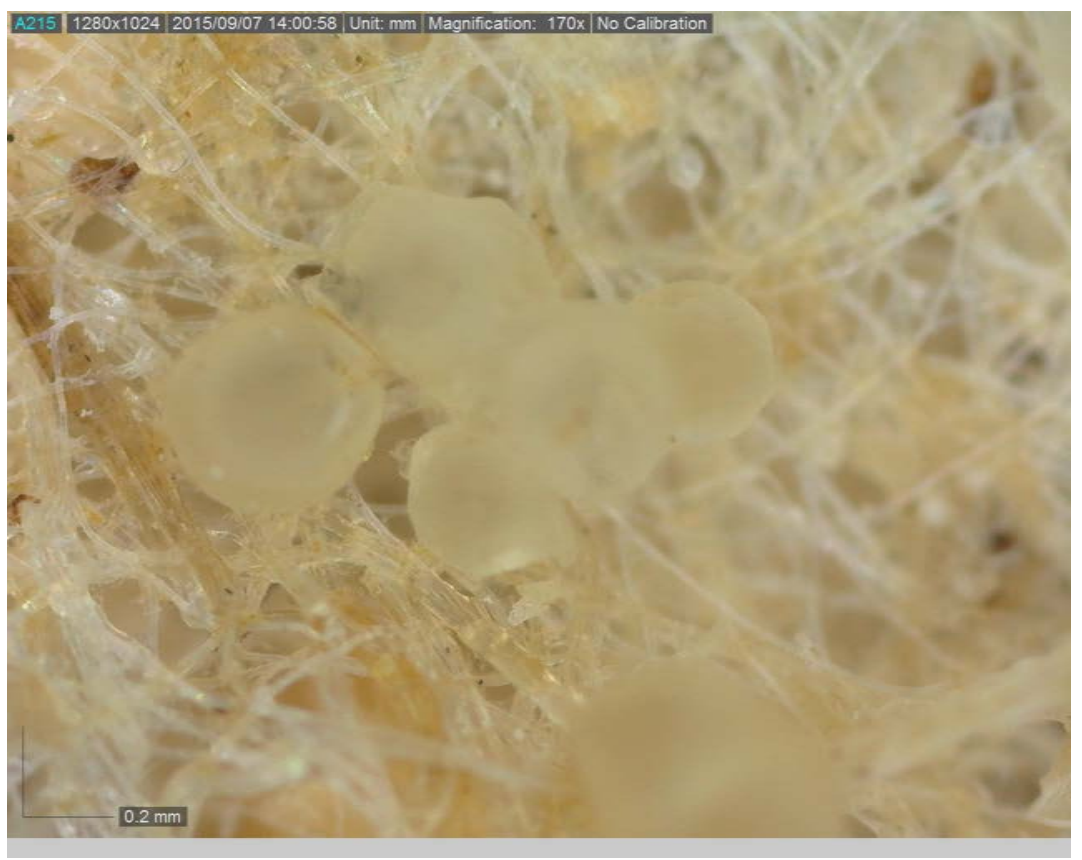

Figure 6. Optical images $(200 \times)$ of hemp nonwovens with the chitosan gel and $30 \mathrm{~g} / \mathrm{L}$ oregano microcapsules.

Table 3. Antimicrobial test.

\begin{tabular}{cccc}
\hline \multirow{2}{*}{ Microorganism } & \multicolumn{3}{c}{ \% Reduction $\left(\mathrm{cfu} / \mathrm{mL}^{*}\right)$} \\
\cline { 2 - 4 } & Origin & Oregano oil & Oregano oil microcapsules \\
\hline Penicillium citrinum & ATCC 1109 & 99.00 & 99.00 \\
Rhizopus oryzae & ATCC 11145 & 99.99 & 99.99 \\
Salmonella enterica & ATCC 14028 & 99.99 & 99.99 \\
Escherichia coli & ATCC 25922 & 99.99 & 99.99 \\
\hline
\end{tabular}

${ }^{*} \mathrm{Cfu}$ is colony forming unit for bacteria.

Oregano microcapsules can be observed in Figure 6. It can be noticeable that their shapes are spherical.

It is possible to calculate the quantity of microcapsules deposited on the nonwoven according to the determination of surface mass.

The microcapsules quantity in chitosan gel was of $30 \mathrm{~g} / \mathrm{L}$, according to the results of Table 4, therefore $6 \mathrm{~g}$ of oregano microcapsules have been deposited on hemp nonwoven.

\subsubsection{Air Permeability}

Air permeability has been studied in order to determine the coating effect (chitosan and microcapsules/chitosan) on the nonwoven. Table 5 shows the results for three replicates.

Attending to the values in Table 5, we could observe that all samples show high levels of air permeability. This parameter is important in nonwoven for agriculture applications, because these substrates should allow water and air to pass in order to improve the soil properties. In this case, the use of chitosan gel as fix polymer didn't affect the permeability. 
Table 4. Results of determination surface mass.

\begin{tabular}{ccccc}
\hline SAMPLES & $\begin{array}{c}\text { TEST 1 } \\
\left(\mathrm{g} / \mathrm{m}^{2}\right)\end{array}$ & $\begin{array}{c}\text { TEST 2 } \\
\left(\mathrm{g} / \mathrm{m}^{2}\right)\end{array}$ & $\begin{array}{c}\text { TEST 3 } \\
\left(\mathrm{g} / \mathrm{m}^{2}\right)\end{array}$ & $\begin{array}{c}\text { AVERAGE } \\
\left(\mathrm{g} / \mathrm{m}^{2}\right)\end{array}$ \\
\hline $\begin{array}{c}\text { Original hemp nonwoven } \\
\text { Hemp nonwoven with chitosan }\end{array}$ & 100.00 & 101.00 & 100.00 & 100.33 \\
$\begin{array}{c}\text { Hemp nonwoven with } \\
\text { chitosan/microcapsules }\end{array}$ & 300.00 & 300.00 & 290.00 & 300.00 \\
\hline
\end{tabular}

Table 5. Results of air permeability.

\begin{tabular}{ccccc}
\hline SAMPLES & $\begin{array}{c}\text { TEST 1 } \\
(\mathrm{mm} / \mathrm{s})\end{array}$ & $\begin{array}{c}\text { TEST 2 } \\
(\mathrm{mm} / \mathrm{s})\end{array}$ & $\begin{array}{c}\text { TEST 3 } \\
(\mathrm{mm} / \mathrm{s})\end{array}$ & $\begin{array}{c}\text { AVERAGE } \\
(\mathrm{mm} / \mathrm{s})\end{array}$ \\
\hline Hemp nonwoven & 1212.42 & 1202.80 & 1190.10 & 1201.77 \\
Hemp nonwoven with chitosan & 889.28 & 890.25 & 885.50 & 888.35 \\
$\begin{array}{c}\text { Hemp nonwoven with } \\
\text { chitosan/microcapsules }\end{array}$ & 860.05 & 856.32 & 864.21 & 860.20 \\
\hline
\end{tabular}

\subsubsection{Water Column Test}

Three replicates were carried out in order to determine the resistance to water penetration (Table 6) in different nonwoven.

Certain sensitive differences in results from water column test can be observed, chitosan gel increases the nonwoven resistance to water penetration. Water column values obtained from nonwovens are lower than results from samples with chitosan. Thus, non-treated nonwovens are not resistant to water penetration under increasing hydrostatic pressure. This results is important thinking in agriculture applications, the functional nonwoven should allow the water penetration.

\subsubsection{Nonwoven Weatherability Resistance}

Table 7 shows the result of weight loss during the 35 days. It compares the initial weight (without exposure) with the weight after weathering. Temperatures were between $20^{\circ} \mathrm{C}-35^{\circ} \mathrm{C}$. During this continuous period it has been recorded rainfall days on days: 10, 31, 33, 34 and 35, with a total amount of $25.8 \mathrm{~L}$.

Before the measurement nonwovens have been conditioned for 24 hours (Temperature: $20^{\circ} \mathrm{C} \pm 2^{\circ} \mathrm{C}$; Relative humidity: $65 \% \pm 4 \%$ ).

As increasing the exposure time, functional hemp nonwovens lost weight due to the chitosan gel is degraded and the microcapsules were broken and the oil is delivered.

Figure 7 shows images from the prototypes during the exposure time. The coating is composed of $30 \mathrm{~g} / \mathrm{L}$ oregano microcapsules and chitosan.

Images show that microcapsules retain their spherical shape during the exposure time, but as time passes it is more difficult to locate the microcapsules because the membrane is degraded, and the oregano essence evaporates and therefore microcapsules lose their shape.

During this continuous period the average temperature has been around $25^{\circ} \mathrm{C}$ and rainfall has been low. Figure 8 shows the rainfall. 


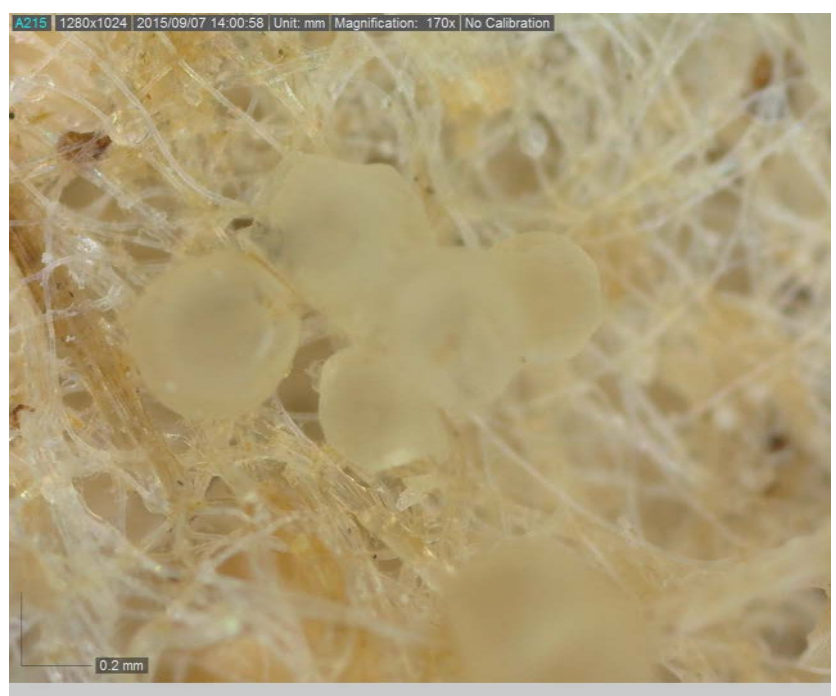

(a)

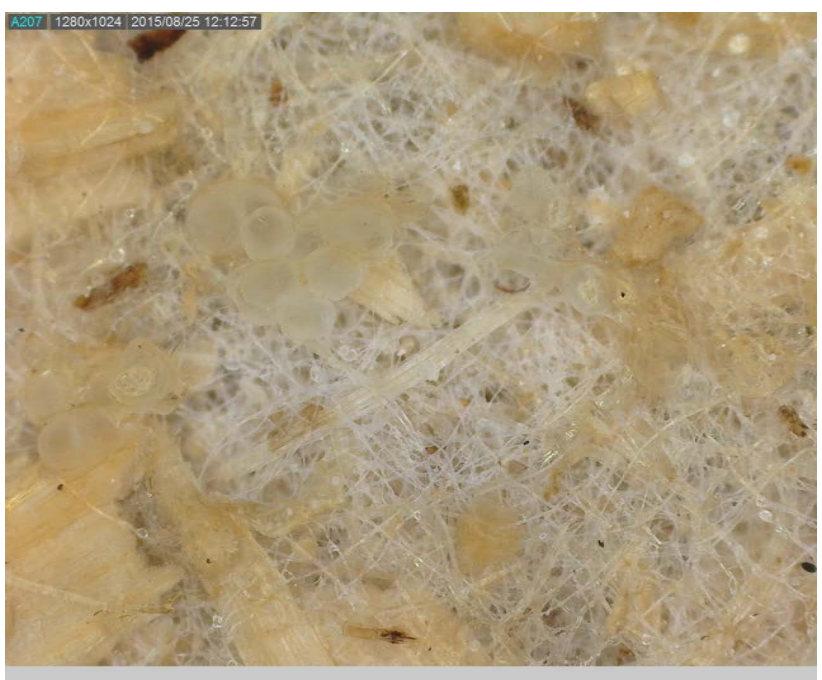

(c)

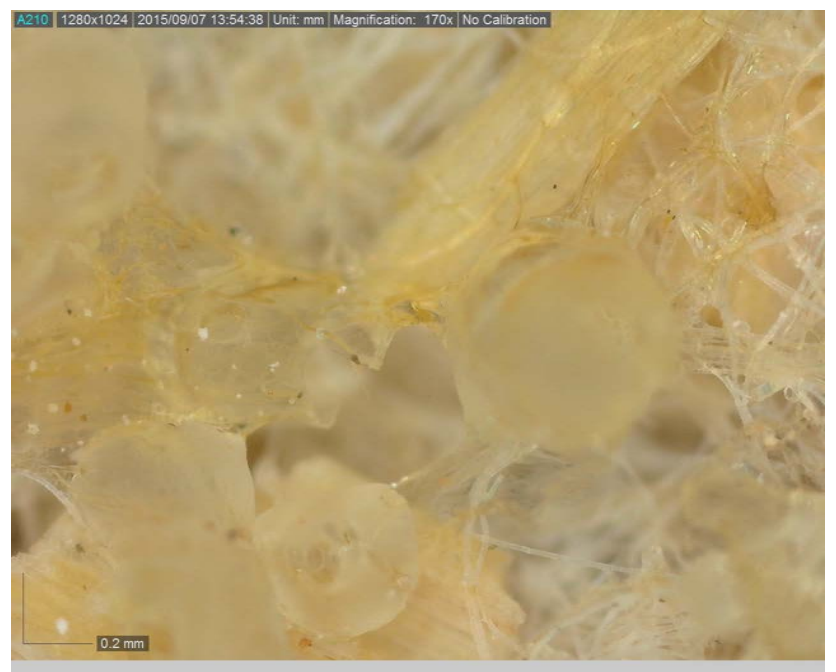

(e)

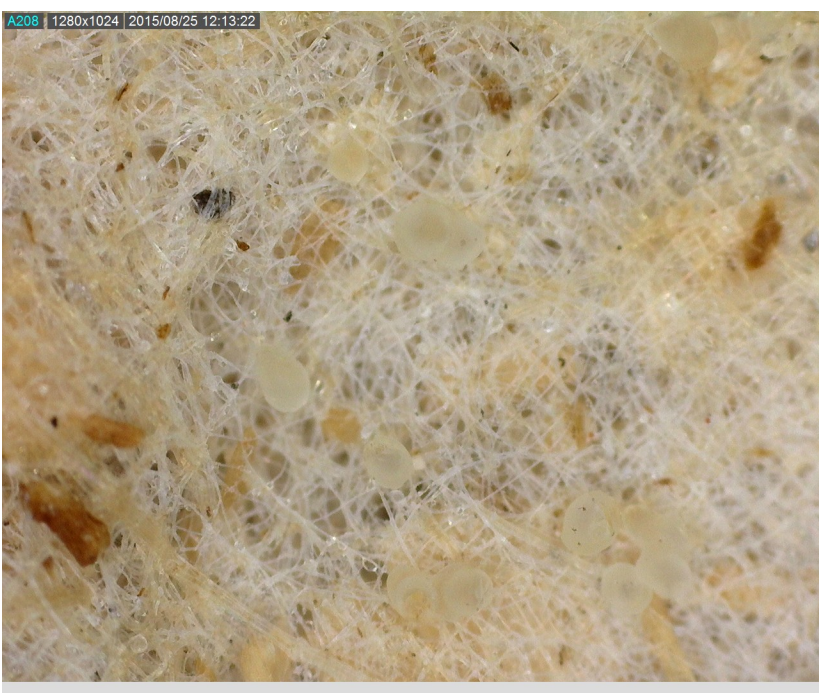

(b)

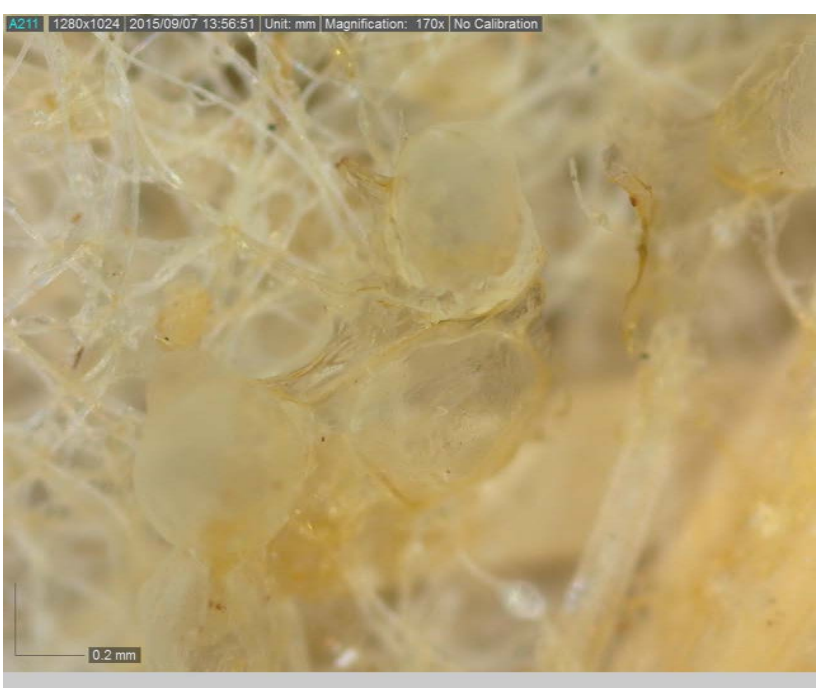

(d)

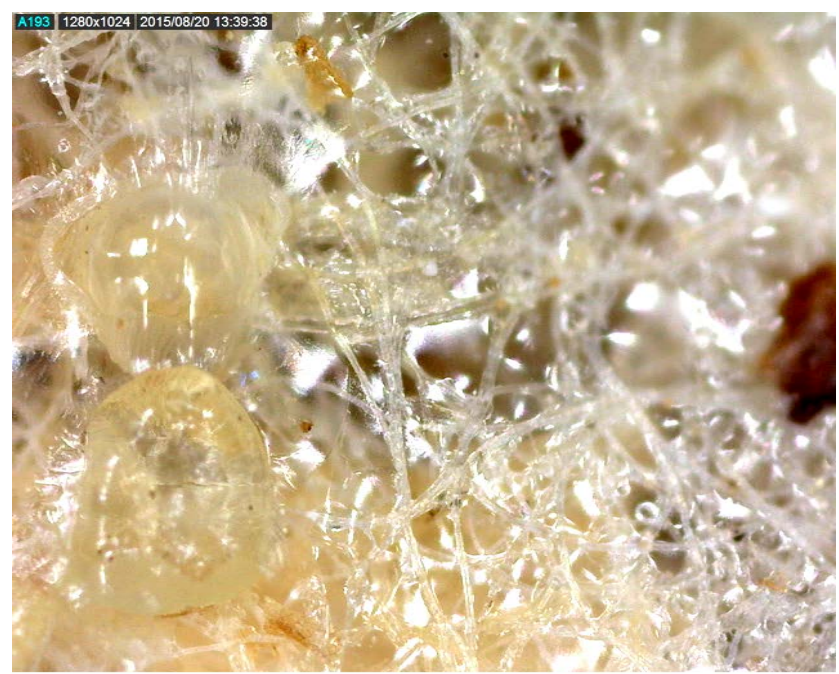

(f) 


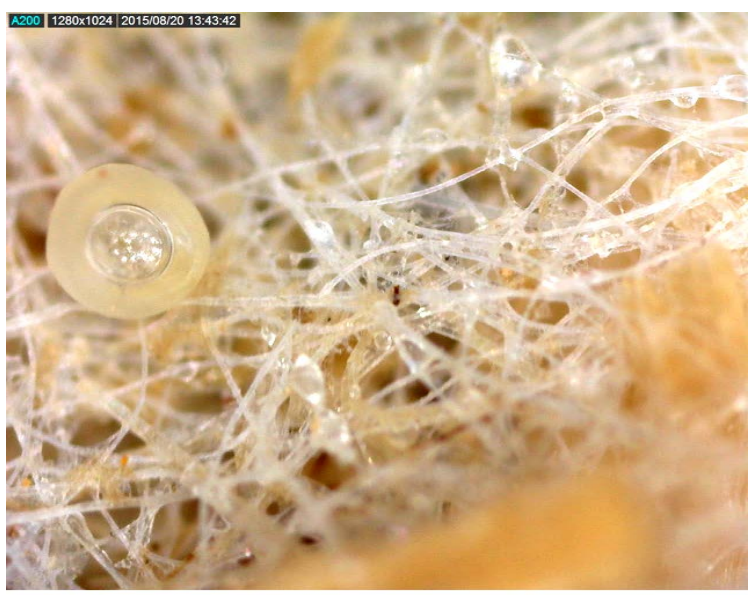

(g)

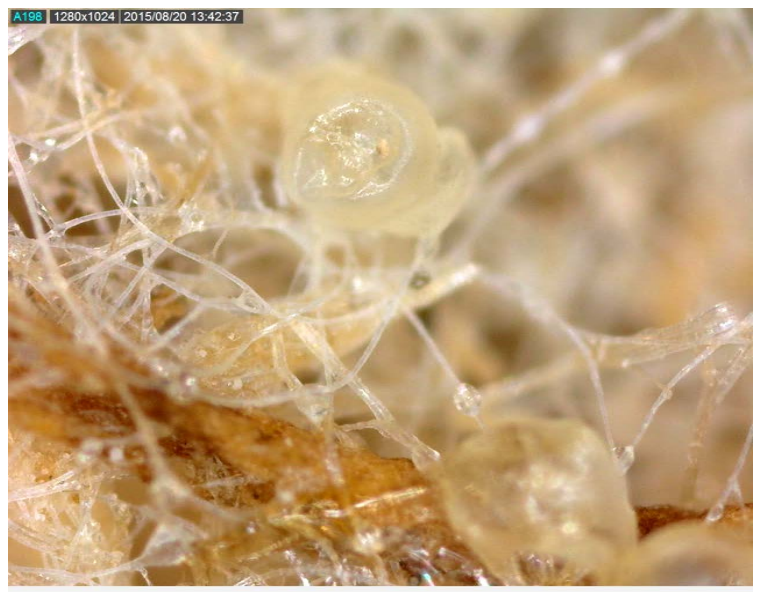

(h)

Figure 7. Optical images (200x) of hemp nonwovens after weathering. (a) initial sample, 0 day; (b) after 4 days; (c) after 9 days; (d) after 14 days; (e)after 19 days; (f) after 24 days; (g) after 29 days; (h) after 35 days.

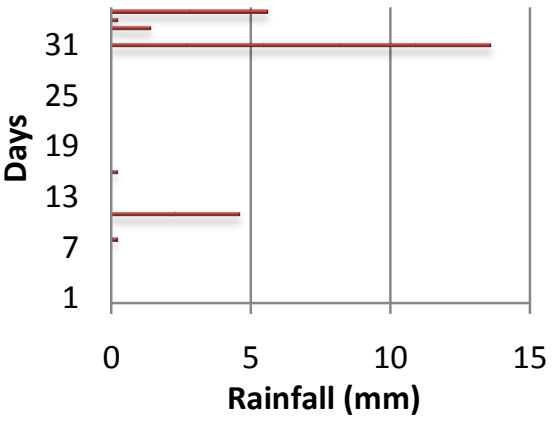

Figure 8. Rainfall during 35 days.

Table 6. Results of water column test.

\begin{tabular}{ccccc}
\hline SAMPLES & $\begin{array}{c}\text { TEST 1 } \\
(\mathrm{cm})\end{array}$ & $\begin{array}{c}\text { TEST 2 } \\
(\mathrm{cm})\end{array}$ & $\begin{array}{c}\text { TEST 3 } \\
(\mathrm{cm})\end{array}$ & $\begin{array}{c}\text { AVERAGE } \\
(\mathrm{cm})\end{array}$ \\
\hline $\begin{array}{c}\text { Original nonwoven } \\
\text { Nonwoven coating } \\
\text { with chitosan gel }\end{array}$ & 3.00 & 4.00 & 3.00 & 3.33 \\
$\begin{array}{c}\text { Nonwoven coating } \\
\text { with chitosan gel + microcapsules }\end{array}$ & 8.00 & 8.00 & 7.00 & 7.67 \\
\hline
\end{tabular}

Table 7. Prototypes weight loss study.

\begin{tabular}{ccc}
\hline Exposure days & Initial weight $(\mathrm{g})$ & Final weight $(\mathrm{g})$ \\
\hline 4 & 1.2 & 1.2 \\
9 & 1.1 & 1.1 \\
14 & 1.4 & 1.2 \\
19 & 1.5 & 1.4 \\
24 & 1.5 & 1.3 \\
29 & 1.3 & 1.2 \\
35 & 1.3 & 1.1 \\
\hline
\end{tabular}




\subsection{Antimicrobial Test Results}

Table 8 shows the antimicrobial test results. It compares an original nonwoven sample without chitosan gel, a sample with the chitosan gel and a sample with the chitosan gel and microcapsules.

Results show that the nonwoven samples which contain the chitosan and microcapsules have a good antimicrobial behaviour if they are compared with the original sample results and the samples with chitosan gel. Chitosan gel samples have a slight antimicrobial activity due to the chitosan properties [49] [50], but the higher efficiency in antimicrobial effect is obtained thanks to the presence of the oregano microcapsules.

This corroborates that the microcapsules endow antimicrobial properties to the nonwoven.

\section{Conclusions}

Microcapsules containing oregano oil were successfully constructed by co-extrusion/gelling using alginate as shell material. The morphology of microcapsules was spherical and the size was determined by optic microscope. The formation of microcapsules confirmed the encapsulation of oregano oil in the alginate shells by identification of the bands and picks which corresponded with the bands in the spectra of oregano oil. Also, the antimicrobial activity of microcapsules was determined, and the results showed that the microcapsules presented the same behaviour of free oil, therefore the encapsulation process didn't affect the antimicrobial activity of the oregano oil. Finally, thermal analysis of microcapsules shows that alginate microcapsules begin their degradation at lower temperatures than free oil. This should be taken into consideration when they are used in a procedure which conditions imply thermal treatment.

On the other hand, hemp nonwoven finished with microcapsules using a chitosan hydrogel presented good results regarding air and water permeability, and both parameters were important in agriculture to improve the soil. Also, the functional nonwoven showed antibacterial activity against different bacteria and fungi. However, more research needs to be done on durability testing and quantitative testing of antibacterial activity in different weather conditions.

Finally, this study demonstrates that the application of microencapsulated compounds on agrotextiles allows functionalization and provides them with new properties.

Table 8. Antimicrobial test results.

\begin{tabular}{ccccc}
\hline \multirow{2}{*}{ Microorganism } & Origin & $\begin{array}{c}\text { Original } \\
\text { sample }\end{array}$ & $\begin{array}{c}\text { Sample } \\
\text { chitosan }\end{array}$ & $\begin{array}{c}\text { Sample chitosan } \\
\text { Microcapsules }\end{array}$ \\
\cline { 2 - 4 } & ATCC 1109 & 0.00 & 0.00 & 99.99 \\
Penicillium citrinum & ATCC 11145 & 0.00 & 5.00 & 99.99 \\
Salmonella enterica & ATCC 14028 & 0.00 & 37.32 & 99.99 \\
Escherichia coli & ATCC 25922 & 0.00 & 61.33 & 99.99
\end{tabular}




\section{Acknowledgements}

The authors thank IVACE (Institut Valencià de Competitivitat Empresarial, Spain) and FEDER (Fondo Europeo de Desarrollo Regional, Europe) for the financial support.

\section{Conflict of Interest}

The authors report no conflict of interest.

\section{References}

[1] Sanjay, M.R., Arpitha, R. and Naik, L. (2016) Applications of Natural Fibers and Its Composites: An Overview. Natural Resources, 7, 108-114. https://doi.org/10.4236/nr.2016.73011

[2] Fedorova, N., Verenich, S. and Pourdeyhimi, B. (2007) Strength Optimization of Thermally Bonded Spunbond Nonwovens. Journal of Engineered Fibers and Fabrics, 2, 38-48.

[3] Kim, H.S., Ito, H., Kikutani, T. and Okui, N. (1999) Computational Analysis on the Thermal Bonding Behaviour of Bicomponentfibres. Journal of the Textile Institute, 90, 508-525. https://doi.org/10.1080/00405000.1999.10750050

[4] Rawal, A., Priyadarshi, A., Lomov, S.V., Verpoest, I. and Vankerrebrouck, J. (2010) Tensilebehaviour of Thermally Bonded Nonwoven Structures: Model Description. Journal of Materials Science, 45, 2274-2284. https://doi.org/10.1007/s10853-009-4152-x

[5] Safavi, A., Fathi, S., Babaei, M.R., Mansoori, Z. and Latifi, M. (2009) Experimental and Numerical Analysis of Fiber Characteristics Effects on Fiber Dispersion for Wet-Laid Nonwoven. Fibers and Polymers, 10, 231-236. https://doi.org/10.1007/s12221-009-0231-5

[6] Laohasongkram K., Mahamaktudsanee T. and Chaiwanichsiri S. (2011) Microencapsulation of Macadamida Oil by Spray Drying. Procedia Food Science, 1, 16601665. https://doi.org/10.1016/j.profoo.2011.09.245

[7] Vidović S.S., Vladić J.Z., Vaštag Ž.G, Zeković Z.P. and Popović L.M.( 2014) Maltodextrin as a Carrier of Health Benefit Compounds in Saturejamontana Dry Powder Extract Obtained by Spray Drying Technique. Powder Technology, 258, 209-215. https://doi.org/10.1016/j.powtec.2014.03.038

[8] Osorio, C., Acevedo, B., Hillebrand, S., Carriazo, J., Winterhalter, P. and Morales, A.L. (2010) Microencapsulation by Spray-Drying of Anthocyanin Pigments from Corozo (Bactris guineensis) Fruit. Journal of Agricultural and Food Chemistry, 58, 6977-6985. https://doi.org/10.1021/jf100536g

[9] Varonaa, S., Karethb, S., Martín, Á. and Coceroa, M.J. (2010) Formulation of Lavandin Essential Oil with Biopolymers by PGSS for Application as Biocide in Ecological Agriculture. Journal of Supercritical Fluids, 54, 369-377. https://doi.org/10.1016/j.supflu.2010.05.019

[10] Varona, S., Martín, A. and Cocero, M.J. (2009) Formulation of a Natural Biocide Based on Lavandin Essential Oil by Emulsification Using Modified Starches. Chemical Engineering and Processing, 48, 1121-1128. https://doi.org/10.1016/j.cep.2009.03.002

[11] Kha, T.C., Nguyena, M.H., Roacha, P.D. and Stathopoulos, C.E. (2014) Microencapsulation of Gac Oil: Optimisation of Spray Drying Conditions Using Response Surface Methodology. Powder Technology, 264, 298-309.

https://doi.org/10.1016/j.powtec.2014.05.053 
[12] Pitalua, E., Jimenez, M., Vernon-Carter, E.J. and Beristain, C.I. (2010) Antioxidative Activity of Microcapsules with Beetroot Juice Using Gum Arabic as Wall Material. Food and Bioproducts Processing, 88, 253-258. https://doi.org/10.1016/j.fbp.2010.01.002

[13] Bagheri, L., Madadlou, A., Yarmand, M. and Mousav, M.E. (2014) Spray-Dried Alginate Microparticles Carrying Caffeine-Loaded and Potentially Bioactive Nanoparticles. Food Research International, 62, 1113-1119. https://doi.org/10.1016/j.foodres.2014.05.040

[14] Malmo, C., La Storia, A. and Mauriello, G. (2013) Microencapsulation of Lactobacillus reuteri DSM 17938 Cells Coated in Alginate Beads with Chitosan by Spray Drying to Use as a Probiotic Cell in a Chocolate Soufflé. Food Bioprocess Technology, 6, 795-805. https://doi.org/10.1007/s11947-011-0755-8

[15] Li, Y., Ai, L., Yokoyama, W., Shoemaker, C.F., Wei, D., Ma, J. and Zhong, F. (2013) Properties of Chitosan-Microencapsulated Orange Oil Prepared by Spray-Drying and Its Stability to Detergents. Journal of Agricultural and Food Chemistry, 61, 3311-3319. https://doi.org/10.1021/jf305074q

[16] Estevinho, B.N., Rocha, F., Santos, L. and Alves, A. (2013) Microencapsulation with Chitosan by Spray Drying for Industry Applications-A Review. Trends in Food Science \& Technology, 31, 138-155. https://doi.org/10.1016/j.tifs.2013.04.001

[17] AniesraniDelfiya, D.S., Thangavel, K., Natarajan, N., Kasthuri, R. and Kailappan, R. (2015) Microencapsulation of Turmeric Oleoresin by Spray Drying and in Vitro Release Studies of Microcapsules. Journal of Food Process Engineering, 38, 37-48. https://doi.org/10.1111/jfpe.12124

[18] Estevinho, B.N., Damas, A.M., Martins, P. and Rocha, F. (2014) Microencapsulation of $\beta$-Galactosidase with Different Biopolymers by a Spray-Drying Process. Food Research International, 64, 134-140. https://doi.org/10.1016/j.foodres.2014.05.057

[19] Rodklongtan, A., La-Ongkham, O., Nitisinprasert, S. and Chitprasert, P. (2014) Enhancement of Lactobacillus reuteri KUB-AC5 Survival in Broiler Gastrointestinal Tract by Microencapsulation with Alginate-Chitosan Semi-Interpenetrating Polymer Networks. Journal of Applied Microbiology, 117, 227-238. https://doi.org/10.1111/jam.12517

[20] Soottitantawat, A., Yoshii, H., Furuta, T., Ohkawara, M. and Linko, P. (2003) Microencapsulation by Spray Drying: Influence of Emulsion Size on the Retention of Volatile Compounds. Journal of Food Science, 68, 2256-2262. https://doi.org/10.1111/j.1365-2621.2003.tb05756.x

[21] Anbinder, P.S., Deladino, L., Navarro, A.S., Amalvy, J.I. and Martino, M.N. (2011) Yerba Mate Extract Encapsulation with Alginate and Chitosan Systems: Interactions between Active Compound Encapsulation Polymers. Journal of Encapsulation and Adsorption Sciences, 1, 80-87. https://doi.org/10.4236/jeas.2011.14011

[22] Soliman, E.A., El-Moghazy, A.Y., Mohy-El-Din, M.S. and Massoud, M.A. (2013) Microencapsulation of Essential Oils within Alginate: formulation and in Vitro Evaluation of Antifungal Activity. Journal of Encapsulation and Adsorption Sciences, 3, 48-55. https://doi.org/10.4236/jeas.2013.31006

[23] Paster, N., Menasherov, M., Ravid, U. and Juven, B. (1995) Antifungal Activity of Oregano and Thyme Essential Oils Applied as Fumigants against Fungi Attacking Stored Grain. Journal of Food Protection, 58, 81-85. https://doi.org/10.4315/0362-028X-58.1.81

[24] Ayala, J.F., Del Toro, L., Alvarez, E. and Gonzalez, G.A. (2008) High Relative Humidity In-Package of Fresh-Cut Fruits and Vegetables: Advantage or Disadvantage Considering Microbiological Problems and Antimicrobial Delivery Systems. Journal 
of Food Science, 4, 41-47.

https://doi.org/10.1111/j.1750-3841.2008.00705.x

[25] Kailasapathy, K. (2002) Microencapsulation of Probiotic Bacteria: Technology and Potential Applications. Current Issues in Molecular Biology, 3, 39-48.

[26] Kwak, H.-S. (2014) Nano- and Microencapsulation for Foods. Wiley, Hoboken. https://doi.org/10.1002/9781118292327

[27] Dolçà, C., Ferrándiz, M., Capablanca, L., Franco, E., Mira, E., López, F. and García, D. (2015) Microencapsulation of Rosemary Essential Oil by Co-Extrusion/Gelling Using Alginate as Wall Material. Journal of Encapsulation and Adsorption Sciences, 5, 121-130. https://doi.org/10.4236/jeas.2015.53010

[28] Monllor, P., Capablanca, L., Gisbert, J., Díaz, P., Montava, I and Bonet, A. (2010) Improvement of Microcapsule Adhesion to Fabrics. Textile Research Journal, 80, 631-635. https://doi.org/10.1177/0040517509346444

[29] Bhattarai, N., Gunn, J. and Zhang, M. (2010) Chitosan-Based Hydrogels for Controlled, Localized Drug Delivery. Advanced Drug Delivery Results, 62, 83-99. https://doi.org/10.1016/j.addr.2009.07.019

[30] Heinzelmann, K. and Franke, K. (1999) Using Freezing and Drying Techniques of Emulsions for Microencapsulation of Fish Oil to Improve Oxidation Stability. Colloids and Surfaces B: Biointerfaces, 12, 223-229. https://doi.org/10.1016/S0927-7765(98)00077-0

[31] Christensen, K., Pedersen, G. and Kristensen, H. (2001) Preparation of Redispersible Dry Emulsion by Spray Drying. International Journal of Pharmaceutics, 212, 187-194. https://doi.org/10.1016/S0378-5173(00)00596-2

[32] Sheu, T.Y. and Rosenberg, M. (1995) Microencapsulation by Spray Drying Ethyl Caprylate in Whey Protein and Carbohydrate Wall Systems. Journal of Food Science, 60, 98-103. https://doi.org/10.1111/j.1365-2621.1995.tb05615.x

[33] Desai, K.G.H and Jin, Park H. (2005) Recent Developments in Microencapsulation of Food Ingredients. Drying Technology, 23, 1361-1394. https://doi.org/10.1081/DRT-200063478

[34] Meunier, J.P. (2007) Use of Spray-Cooling Technology for Development of Microencapsulated Capsicum Oleoresin for the Growing Pig as an Alternative to In-Feed Antibiotics. A Study of Release Using in Vitro Models. Journal of Animals Science, 85, 2699-2710. https://doi.org/10.2527/jas.2007-0027

[35] Balassa, L.L., Fanger, G.O. and Wurzburg, O.B. (1971) Microencapsulation in the Food Industry. Critical Reviews in Food Science \& Nutrition, 2, 245-265. https://doi.org/10.1080/10408397109527123

[36] Hernández, G. and Tisnado, R. (2012) Avances tecnológicos en la producción de alginatos en México. Ingeniería Investigación y Tecnología, 2, 155-168.

[37] Ferrándiz, M., Capablanca, L., García, D., Bou, E. and Gutierrez, O. (2015) Estudio de la capacidad de desintegración de agrotextiles obtenidos a partir de fibras biodegradables. Revista de la Asociación Española de Químicos y Coloristas, 214, 12-19.

[38] Feditchkina, E. (2014) The Promise of Biological Control for Sustainable Agriculture: A Stakeholder-Based Analysis. Journal of Science Policy \& Governance, 5.

[39] Nussinovitch, A. (2016) Encapsulation in Agriculture/Aquaculture. Bioencapsulation Research Group, Vol. 44, 1.

[40] Chang, I., Im, J. and Chun, C.G. (2016) Introduction of Microbial Biopolymers in Soil Treatment for Future Environmentally-Friendly and Sustainable Geotechnical Engineering. Sustainability, 8, 251. https://doi.org/10.3390/su8030251 
[41] Capablanca, L., Bonet, M., Bou, E., Ferrándiz, M., Franco, E. and Dolçà, C. (2014) Aplicación de técnicasbiotecnológicas y de microencapsulación para la funcionalización de agrotextiles. 2th Congreso de I+D+I Campus Alcoi: Creando Sinergias, Alcoi, 12 November 2014, 17-20.

[42] Chan, E.S., Lee, B.B., Pogaku, R. and Poncelet, D. (2009) Prediction Models for Shape and Size of Ca-Alginate Macrobeads Produced through Extrusion-Dripping Method. Journal of Colloid and Interface Science, 338, 63-72. https://doi.org/10.1016/j.jcis.2009.05.027

[43] Hoffman, A. (2012) Hydrogels for Biomedical Applications. Advanced Drug Delivery Reviews, 64, 18-23. https://doi.org/10.1016/j.addr.2012.09.010

[44] Al-Sheibany, I.S., Kadhim, K.H. and Abdullah, A.S. (2005) Qualitative and Quantitative Evaluation of Some Organic Compounds in Iraqi Thyme. National Journal of Chemistry, 19, 366-379.

[45] Kumar, S., Panner, R. and Sivakumar, T. (2010) Isolation, Characterisation and Formulation Properties of a New Plant Gum Obtained from Mangiferaindica. International Journal of Pharmaceutical and Biomedical Research, 1, 35-41.

[46] Schulz, H., Özkan, G. and Barkansa, M. (2005) Characterisation of Essential Oil Plants from Turkey by IR and Raman Spectroscopy. Vibrational Spectroscopy, 39, 249-256. https://doi.org/10.1016/j.vibspec.2005.04.009

[47] Lawrie, G., Keen, I., et al. (2007) Interactions between Alginate and Chitosan Biopolymers Characterized Using FTIR and XPS. Biomacromolecules, 8, 2533-2541. https://doi.org/10.1021/bm070014y

[48] Sivropoulou, A., Papanikolaou, E., Nikolaou, C. and Lanaras, T. (1996) Antimicrobial and Cytotoxic Activities of Origanum Essential Oils. Journal of Agricultural and Food Chemistry, 44, 1202-1205. https://doi.org/10.1021/jf950540t

[49] Mayur, G., Rajshree, C., Jolly, M. and Vijay, B. (2005) Papain Entrapment in Alginate Beads for Stability Improvement and Site-Specific Delivery: Physicochem- ical Characterization and Factorial Optimization Using Neural Network Modeling. AAPS PharmSciTechv, 6, 209-222. https://doi.org/10.1208/pt060231

[50] Goy, R.C. and Britto, D. (2009) A Review of the Antimicrobial Activity of Chitosan. Polímeros: Ciência e Tecnologia, 19, 241-247. https://doi.org/10.1590/S0104-14282009000300013

Submit or recommend next manuscript to SCIRP and we will provide best service for you:

Accepting pre-submission inquiries through Email, Facebook, LinkedIn, Twitter, etc. A wide selection of journals (inclusive of 9 subjects, more than 200 journals)

Providing 24-hour high-quality service

User-friendly online submission system

Fair and swift peer-review system

Efficient typesetting and proofreading procedure

Display of the result of downloads and visits, as well as the number of cited articles

Maximum dissemination of your research work

Submit your manuscript at: http://papersubmission.scirp.org/

Or contact jacen@scirp.org 